\title{
From Europe with passion: frameworks of the touristic male desire of Ponta Negra, in the North-East of Brazil
}

\author{
Octávio Sacramento* \\ Department of Economics, Sociology and Management, Centre for Transdisciplinary \\ Development Studies-University of Trás-os-Montes and Alto Douro, Vila Real, Portugal
}

(Received 28 February 2015; accepted 25 May 2015)

\begin{abstract}
Based upon multi-sited ethnographic fieldwork, this article debates the constitution of a particular type of transatlantic touristic flows from the European continent to the cosmopolitan beach neighbourhood of Ponta Negra, in Natal, capital city of the state of Rio Grande do Norte in the North-East of Brazil. These flows are predominantly male and are quite evidently permeated by issues related to passion, personal relations and sexual intimacy. The main objective of the analysis is to attempt to map and understand the most influential social and cultural frameworks (biographical paths of intimacy, gender relationships, subjectivities, the production and circulation of representations of Brazil, homosociabilities) in the definition and substantiation of the foreign male tourist's desire to visit Ponta Negra. It thus constitutes an attempt to socially and culturally locate the option of travelling to this leisure destination, on the part of both first-time visitors and the numerous individuals who repeatedly visit Ponta Negra over the years.
\end{abstract}

Keywords: tourism; European men; sociocultural frameworks; transnational desires; Ponta Negra; Brazil

\section{Introduction}

The European countries have been the privileged interlocutors in the developing process of the beach neighbourhood of Ponta Negra, in Natal-RN (North-East Brazil), into a global touristic site. To prove it, immediately, is the highlighted position of Europe in the emission of international flows of people who go there, constituted predominantly by men coming from the Mediterranean region. During their stays, they often establish close interactions with local women - especially in the context of transactional sex (programas) associated with the touristic phenomenon - and from which different configurations of transnational intimacy result. During the fieldwork for my Ph.D. related to this theme (Sacramento, 2014), I was concerned in apprehending the heterosexual emotional and sexual relationships between European visitors and adult Brazilian women, as well as the development of their passion connections into forms of conjugality and the resulting transatlantic flows. ${ }^{1}$

It is through this project that I try to develop here an analysis more focused in the masculine tourist mobility from Europe to Ponta Negra, paying special attention to the case of Italy, the main country of origin of tourist visitors there. Generally, these transnational flows are heavily marked by issues of passion, similar to what happens in other tropical destinations worldwide, namely in Latin America (Blanchette \& Silva, 2010; Brennan,

\footnotetext{
*Email: octavsac@utad.pt
} 
2004a, 2004b; Kempadoo, 1999; O’Connell Davidson, 1996; Piscitelli, 2004a; 2007; Simoni, 2014) and in Southeast Asia (Bishop \& Robinson, 1998; Cohen, 1982, 2003; Garrick, 2005; Hoefinger, 2013; Leheny, 1995; Leung, 2003; Oppermann \& McKinley, 1997; Truong, 1983, 1990). Essentially, the identification and detailed understanding of the main frameworks - personal circumstances, key episodes in the protagonists' lives, aspects of symbolic production, sociability and subjectivities - linked to this type of mobility, constitute the central aim of the present analysis. In this way, it was possible to trace the emergence and development of these touristic flows and assess to what extent the majority of them are, intrinsically, permeated by desiderata related to interpersonal intimacy. This implies, undoubtedly, looking forward (as well), considering the everyday lives and life expectations and projects (mainly at the level of (inter)personal feelings and intimacy), as well as the images, representations and other social influences that, in the country of origin, help to configure the decision to go to Ponta Negra for the first time, or to repeat visits, as is the case with some of my informants. The fact that I was able to encounter them, first on the Brazilian side of the ocean and subsequently in their contexts of origin, gave me a wider and more complex perspective on the social frameworks that their touristic experiences involve. Furthermore, it allowed me to access the corresponding networks of male relationships, to get to know other informants who intended to accompany them on their next trips to Ponta Negra, and thus, to understand some of the main constitutive processes of the intentions (and desires) that inform the decision to visit (and revisit) this tourist location.

Though expectations of transitory erotic-sexual encounters and more permanent conjugal outcomes are both present in this back-and-forth flow of male travellers, I adopt a critical distance from the notion of 'sexual tourism', a conceptual framework that is typically used to refer to situations in which there is an overlap between tourism and prostitution, as well as other forms of intimate relationships between visitors and locals (Bandyopadhyay, 2013; Bishop \& Robinson, 1998; Brennan, 2004a; Carrier-Moisan, 2012; Cohen, 1982; Leheny, 1995; Kempadoo, 1999; O’Connell Davidson, 1996; Oppermann, 1999; Piscitelli, 2009; Rao, 1999; Taylor, 2001; Williams, 2013). I have justified this option on two main grounds (Sacramento, 2011): the moral and ideological straightjacket in which the concept is often constrained; and its imprecise nature and epistemological incoherence. The semantic field to which it is attached is so poorly defined, volatile and multi-paradigmatic (Ryan, 2000; Taylor, 2001) that it can be used as an analytical reference for empirical manifestations as distinct as, for example, child sexual exploitation and commercial/non-commercial sexual relations between consenting adults. Furthermore, it is a reductionist concept because European tourists do not only seek the commercial consumption of 'sex for the sake of sex' during their holiday visits. Moreover, the analysis of the social frameworks that drive the configuration of the touristic desire of Ponta Negra provides us with contextual elements that may allow us to more readily question the 'sex-centric' perspective of sexual tourism and develop a more multifaceted and useful analysis.

\section{Men and passional turbulence in the Old Continent}

The tourism from Europe to Ponta Negra is undertaken mainly by men and, in particular, by men together in groups. These European tourists exhibit a duality based on gender and nationality that contrasts sharply with the rest of the local tourist scene, in which there is an almost total absence of groups constituted only by European women. ${ }^{2}$ In line with the conclusions of researchers on other destinations with similar profiles (Fernandez, 1999; Gomes, Silva, Cavalcante, \& Fonteles, 2010; O’Connell-Davidson, 1996; Piscitelli, 
2004b; Trumbull, 2001), the results of the short questionnaire on the social profile of European visitors that I conducted on the beach at Ponta Negra pointed to a significant predominance (around two thirds) of Italians (Sacramento, 2014), justifying my choice of centring the analysis on tourists of this nationality. The majority comes from the north of the country, particularly from great urban centres such as Milan and Turin. The greater purchasing power of the northern population and the fact that changes associated with the second demographic transition, especially with regard to marriage, are more intense there than in the South (Billari \& Rosina, 2007) ${ }^{3}$ are key to our understanding of why the major part of these male tourist flows originate in the North of Italy.

In addition to their geographical origin, these male tourists have other general social characteristics of interest, namely: ( $i$ ) the majority is between 26 and 45 years of age, (ii) their education level is intermediate, that is, they have completed secondary or technicalprofessional training, (iii) the most prevalent employment category is the assistant (e.g. sales assistant), followed by the factory worker, ${ }^{4}$ (iv) more than two-thirds are single and the rest are equally distributed between married or divorced/separated (Sacramento, 2014, pp. 157-160). Their lives mirror many of the socio-demographic features of European countries in general - increasing bachelorhood and divorce, later marriage, lower rate of marriages, lower birth rate - directly associated with ongoing changes in the family, shifts in Western models of intimacy, changes in gender identity and relations, the individualization of personal life, the increasing volatility of interpersonal attachments, and new settings for marital and parenthood ties (Aboim, 2004; Bauman, 2008; Beck \& Beck-Gernsheim, 2004; Giddens, 2001; Illouz, 1999; Roca, 2008). A part of these ongoing changes in men's intimate life and gender relationships, and the ideologies of masculinity with which they articulate, constitute social frameworks that are important if we are to understand the circumstances that awake the male desire to travel from Europe to Brazil, the underlying expectations of intimacy they may nurture, and the emergence of transnational couples (Roca, 2007).

Ponta Negra's high proportion of single visitors and the substantial percentage of tourists who are divorced or separated, reflect the 'transformation of intimacy' (Giddens, 2001) in European countries, namely in the models of the emotional relationship and forms of conjugality (Coontz, 2004) that generate the social conditions and subjective dispositions most favourable to what might be described as the transnationalization of passion. The difficulties, discontinuity and dissatisfactions of relationships in Europe, already focused in other works (O'Connell-Davidson, 2001; Piscitelli, 2004a), constitute important aspects of the intimate lives of these men, expressed in several moments of the process of negotiation of intimacy and in the construction of conjugal projects. In their own words, the emancipation of the European woman is one of the main causes for the turbulence that affects the organization of their own intimate lives. In contrast, the Brazilian woman represents a model of gender that is more similar to what they consider 'normal' in terms of male and female identities. In the tropics, they hope to find relational and identity options that ostensibly have become scarce in Europe, thereby opening up the possibility of recapturing (even if only fleetingly) the 'natural' places occupied by men and women before they were 'undermined' by Western feminism. Leaving aside the ideological distortions present in the ethnographic subjects' concerns and expectations, the latter also constitute subjectivities that promote the pursuit of what they desire and what they think may be found somewhere else: ' [ ... ] many Northern men do experience some form of existential disempowerment brought by the erosion of patriarchy and "traditional" family values in the Northern public sphere, and seek to reaffirm their domination [...] in the Global South' (Veissière, 2011, p. 31). 
Each time I questioned my informants ${ }^{5}$ about their emotional life in their home contexts, almost all emphasized their difficulties in establishing romantic connections. The analogy that one of my main informants, Giacomo (Italian, 58 years old, retired), made with the legendary Rape of the Sabine women is revealing: In the pre-imperial epoch, the Romans carried off the Sabine women because they had none of their own. Likewise, the Italians of today, whose opportunities to conquer women are scarce and fraught with difficulty, are forced to seek them here [Brazil]. Informants usually identified this absence of opportunities for heterosexual conquest as the result of European women's marked tendency to selectively refuse male attempts at seduction. In contrast, the South American woman is supposedly more welcoming of male approaches: Here [Brazil], if I look at a woman and talk to her, she will talk to me, even if she doesn't want to stay with me afterwards. She will talk ... In Italy, she won't talk. She will be silent, or just say 'No, no'. That is rude. I don't like it! (Italian, 23 years old, carpenter). In addition to conquest being a very demanding process, respondents also highlighted the length of time it takes in Europe for the sexual phase of a relationship to develop: In Italy, first you get to know the woman. Then you take her out for dinner. The ... n [spoken with a long, drawn out intonation], after a long time, maybe you can take her to bed (Italian, 35 years old, pharmacy assistant).

In general, the Italians I extensively interviewed alleged attributed the more closed behaviour of European women ${ }^{6}$ to their overly selective and strict expectations, when compared, for instance, to what happens in Brazil. Giacomo would repeatedly tell me that the European woman, and Italian woman in particular, longs for a successful, proud and prestigious man, just like the celebrities she sees on television. In his opinion, Flavio Briatore (exdirector of the Renault and the Benetton Formula 1 teams) and Francesco Totti (the Roma football player) would be good examples of the most desirable model male. These icons are admired by both men and women, symbolising what Connell (1995) calls 'hegemonic masculinity', that is, the type of male identity that has greater general pre-eminence in a specific social context and at a specific historical moment, thereby constituting the prototype that men wish to embody, and providing the yardstick by which their behaviour is evaluated and ranked as being closer to or further from the ideal ('subordinated masculinities'). ${ }^{7}$ Any deviation from the most valued criteria of masculinity and associated difficulties in heterosexual seduction tend to be translated by men as a problem of (in)definition of their own gender identity. It should be remembered that a man's success in gaining intimate access to a woman is a central - albeit relative and not exclusive - axis of the hegemonic values regarding masculinity (Almeida, 1995; Bozon, 2004).

In addition to the allegedly demanding and reluctant attitude of European women in matters of the heart, many Italian men identified their own middle age as a factor that reduces their possibilities of success in the love and matrimonial markets of their countries of origin. In their opinion, due to prejudice related to age difference, it is more difficult accessing younger women (from other generation), especially the more valued and desired women; those who in Italy, according to Giacomo, might be seen as matching the ideal of the velina. ${ }^{8}$ On the other hand, the majority of women of their own generation are already out of the public circuits of seduction: In Italy, a man who is 35 years of age is already too old to look for a woman. [... ] You go out, but you only find women of 20-25. Women of my age rarely go out at night (Italian, 35 years old, unemployed psychologist). Among the tourists, there was a profound conviction that, in the Brazilian context, the age difference would cease to be a relevant obstacle in establishing relationships with the opposite sex. In fact, in Brazil, there seems to be a higher social acceptance of age differences and a certain cultural tendency for women to prefer older partners (Knauth, Víctora, Leal, \& Fachel, 2006). 
Against a background of post-colonial structures of power, consisting of multiple axes of social positioning such as class, nationality, 'race', gender and ethnicity (McClintock, 1995), opportunities for transatlantic travel have added a new dimension to European men's status in gender relationships. It allows them to date relatively young partners - women who, in comparison to their European counterparts, they consider more socially and sexually docile and who therefore match more closely to the values and symbols of the still dominant model of masculinity to which they adhere. ${ }^{9}$ Their aspiration to fulfil their ideal of virility moulds their desires and fantasies about Brazilian women. Using his usual eloquence, Giacomo described this point as follows: Here [in Ponta Negra, Brazil], I can have my Naomi [Campbell]! Here, I am just like Briatore, even though I'm not a millionaire. As in many other cases, in Brazil, he found a type of partner that he would hardly find in Italy, therefore fulfilling a major criterion in the validation of what was - to him - a muchcoveted gender identity.

It is not only the lack of access to female intimacy in their countries of origin that disillusions the majority of Italian men whom I contacted during my fieldwork, and that leads them to a profoundly negative vision of gender relationships in Europe; the sustaining and consolidation of love affairs is also seen with some degree of disappointment, as a result of personal experiences that diverge significantly from the ideals of romantic love that, in spite of all, continue to assume great importance in defining the contemporaneous emotional life (Beck \& Beck-Gernsheim, 2004). The allegedly excessive female focus on career was frequently identified as the main cause for successive interpersonal incompatibilities and the break-up of relationships, suggesting that these males find themselves in an impasse: they have difficulty in adapting to new gender roles, and thus seek less emancipated women because they are a fundamental condition for a more stable and lasting relationship.

Many of these men, earlier in life, thought they had already found the right woman who would embody the romantic expectations they projected onto marital and family life. Some of them formalized the relationship through marriage, sometimes preceded by a period of cohabitation. Others have established a more informal form of relationship based on cohabitation. ${ }^{10}$ Almost all these ties eventually came to an end, thereby creating both the objective circumstances and the subjective conditions for the exploration of new geographies of passion, such as Brazil. Sometimes, break-ups occurred immediately before a lone tourist trip that had been prearranged as an escape that symbolized a shift in the way these men viewed and organized intimate relations, or to somehow pay tribute to the misfortunes of love, or as a celebration of individuality regained: We came for the first time last year. In December, both of us [he and his friend] told our girlfriends, our partners: That's enough! And then we came to Brazil for a week (Italian, 35 years old, pharmacy assistant).

In some cases, these men experienced deep pain and disappointment at this break with a long-term partner. It represented the collapse of the life they had planned and wished for, envisioned and made concrete through the relationship with their former partner. They explicitly identified its collapse as the major reason for their now constant tourism, for their disaffection with inter-gender relationships in their home countries and for the transnational scope of their search for intimacy. The story of another close informant (Gentile, Italian, 48 years old, mason), whose testimonies were central to my research, exemplifies and illuminates this situation:

In Italy I lived with someone for six years. When I was 21 , I invested in a business in the town where I live. I worked hard, thinking about saving up to buy a house and start a family. Six years later, I paid back the bank for the loan and then my girlfriend told me she had someone else. I felt terrible ... disappointed with women and with the idea of a family! I sold everything, got my 
passport and travelled around the world. Till then I had never left Italy. [ . . . ] I felt I had to do something. To start with, there was a safari in Africa for a month. I came back home and two weeks later I packed my bags again, got my dog and my two-seater car and just drove: Czechoslovakia, Hungry and Romania. I returned a month later and found a job in a friend's construction company. Afterwards I began to travel every year ... the trips became an addiction. I have to travel every year. I just feel ... well ... my life only makes sense if I travel. I only work to travel. [... ] I have been mostly in Latin America. I have been in Colombia, Venezuela, Mexico, Cuba, the Dominican Republic and Brazil.

In addition to marital misfortunes and a general disenchantment with gender relationships in Europe, another situation encountered, albeit less frequently, is when a male tourist's stay in Ponta Negra is preceded by and inseparable from the emotional void experienced after the death of his wife. Mainly among older tourists, widowhood and its consequences - in particular, the possibility of breaking with time-honoured routines and 'rewarding oneself' for a life devoted to family and work, markedly contributes to transatlantic touristic mobility. For these visitors, as for Brazil's foreign tourists in general, the country's sociocultural ecology appears wholly conducive to enjoying life, able to compensate for the rigours of an everyday life enmeshed in multiple work-related and family obligations, and to provide alternatives to the gender constraints and for the emotional turbulence they associate with the Old Continent. In short, Brazil represents a source of alternative patterns of intimacy and identity and gender relations that are closer to the hegemonic ideals of masculinity they so intensely desire.

\section{Representations, male sociability and the emergence of the touristic desire}

If shifting gender structures and men's emotional disquiet in Europe constitute an important social setting for the attractiveness of a holiday resort to male tourists from overseas, then representations of Brazil in general and of Ponta Negra in this particular case, are the seed from which tourist expectations and intentions grow and which in turn promote transatlantic mobility. These representations are based on global images of exoticism, sensuality, eroticism and the allure of inter-racial sex(ual relations) that are generally associated with the feminine, and especially with the paradigmatic image of the mulatto woman (mulata). They have been drafted in the context of the European imperialism and overseas expansion in the eighteenth and nineteenth centuries (Stolcke, 2006) and later adopted by postcolonial Brazil as fundamental references in political, literary, scientific and tourism discourses (among others) for the cultural production of a national identity (Filho, 2011; Machado, 2009; Sommer, 2004). The founding of great overseas empires established geopolitical hierarchies and transnational economies, one of whose effects was to create a solid basis for the symbolic colonization of the tropics - the 'porno-tropics' of the European imaginary (McClintock, 1995), a vision that has been contributing significantly to the genesis of leisure and pleasure geographies. The sexualized conceptions of these tropical contexts, combined with specific ideas regarding 'race' and gender, led to many of them being global portrayed as 'sites of desire', which in turn the tourism industry transformed into 'economies of pleasure' (Mandersen \& Jolly, 1997).

The association of Brazil with sensuality was central to the discourse of tourist promotion (Alfonso, 2006; Bignami, 2002; Ribeiro \& Sacramento, 2009; Sacramento \& Ribeiro, 2013). Albeit not entirely deliberately, this discourse reflected the dominant values of masculinity and was directed above all at the 'gaze' of the white heterosexual male (Pritchard \& Morgan, 2000), thereby reproducing at the same time the pre-existing 'cultural logics of desire' (Constable, 2003) that had been forged in the power structures 
of the colonial and post-colonial political economy. In this discursive regime, the main iconographic elements were beach, samba and mulata. Much of the fascination and seduction inherent in Euro-Brazilian configurations of intimacy draw on these references, especially the representation of Brazil as embodied in the erotic alterity of the mulatto woman.

Nowadays, these representations of Brazil as intrinsically sensual are massively reproduced through a vast articulated complex of cultural industries and widely disseminated through global information and communication systems, nurturing both fantasies of the exotic among the many as well as a certain colonial nostalgia in the former metropolises (Hall, 2007, pp. 79-80). Exposed to the flow of images and discourses constitutive of 'brazilianness', almost all the tourists had already internalized some of its symbolic denominators - particularly those related to its sexualized representation - before they knew any details of a Brazil they could experience for themselves, or before considering it as leisure destination: Before I came here, Brazil for me was ... beaches, sun, women (Italian, 34 years old, salesman). These men generally display this geographical imaginary as a result of a diffuse and cumulative assimilation of a range of representational contents. It is a process that comes from the contact with multiple expressions of identity related to Brazil and Brazilians, all of which are packaged and marketed in a multisensory manner that arouses fascination, empathy and desire. The following testimony illustrates this point:

\begin{abstract}
My image of Brazil started with colour. The yellow and green of the flag ... are very evocative colours. And the location, close to the equator ... you already get the idea of an exotic country. [ ... ] Then, there was the myth of the 1982 Brazilian time [national football team], the one with Telê Santana. It was a dream team, very different from the Italian football, which was very rough! It had all the fantasies. Everything was show de bola [awesome]! It made you imagine all sorts of fantastic things. I was still very young but I started to see Brazil as all fantasy and creativity. [...] Then, when I was 15 or 16, at parties (when parties began to 'explode') the classic song was by Jorge Ben Jor, Fio maravilha [interviewee starts singing the song] ... and everyone would party!!! And the Benito di Paula, with Charlie Brown [again, begins to sing the song] ... At those parties, in Italy, those songs were a must. [ . . ] Music, football and then capoeira. I was curious about the dance, the body movements. But before ... in Italy, when I was younger there was a TV show called Te lo do io il Brasile [I'll give you Brazil]. It was the Italian comedian Beppe Grillo's show. Italian TV gave him money to travel throughout Brazil. I really loved this guy and he let me discover all of Brazil, from top to bottom. He would go to a samba school at Carnival ... he talked about the Brazilian women ... bundas [bottoms], pretty women and also transvestites. [... ] I saw many films about Brazil. (Italian, 35 years old, unemployed psychologist)
\end{abstract}

In addition to the mediatized elements and the products of the cultural industry, the tales told by those who have already been there also contribute to neophyte's notions of Brazil. The interpersonal transmission of ideas and experiences constitutes an important albeit informal way of making a country more familiar beyond its borders. Moreover, it is the tourists themselves who function as the main vectors by which Ponta Negra becomes known to a wider public: after returning to Europe, they informally share their experiences with their own social networks. In fact, they are the ones who frequently make it possible for new visitors to go to a specific resort whose reputation in the 'global imagination' (Appadurai, 1996) of tourist Brazil cannot compare, for example, to that of Rio de Janeiro. The following description demonstrates the importance of friends' recommendations: None of us [he and his friend] thought of coming to Ponta Negra, to Natal. It is obvious that when we think of Brazil we think of Rio, Bahia ... not Natal. The first time I was told about Natal was by some friends who spend their holidays here (Italian, 40 years old, manager of a small company). It is through giro de parole (word 
of mouth) - as the Italian tourists would tell me - that a domino effect is produced within groups of male friends, spreading the wish to visit the resort, and forming the associated chains of mobility. These chains help to explain the significant volume of male tourist flows from the same origin, sometimes from small Italian towns like Ivrea, Aosta or Forli.

A period of fieldwork spent in the North of Italy, after returning from Ponta Negra, allowed me to participate in the spheres of male sociability where word of mouth propagates particular narratives about Brazil. Those who have already been on the other side of the Atlantic tell and retell stories of their experiences, ${ }^{11}$ in particular their amorous adventures. At the same time, they reproduce the main notions of (feminine) sexualized exoticism in the Brazilian identity, articulated with the idea of the uncomplicated woman, open and warm, as opposed to the emancipated European woman, demanding, closed and cold. In this narrative process, there is usually an exaggerated emphasis on the alleged facility of amorous conquests in the tropics, and a downplaying of situations in which payment was involved, as some informants admitted: The illusion of easiness ... everyone talks about that in Italy. They talk about women throwing themselves at you and how they lack complexes and are warm in bed. But they only tell half the story. They don't say that they are not all like that and that for some you have to pay (Italian, 34 years old, electrician). In Italy, the more or less fantasized tales of those who have been to Ponta Negra awaken expectations of delight in their friends, stimulating their curiosity and desire to see for themselves the seductive distinctiveness they have heard described.

In the highlands of Aosta, during an afternoon of male camaraderie at the house of one of Gentile's workmates, seated around a table covered with bottles of wine and genepi (alpine herb liquor), I witnessed a revealing example of the extent to which homosociability is responsible for constituting a desire to visit particular tourist destinations. At that time, he was sharing the knowledge he had accumulated during his innumerable two-to-three month stays in Ponta Negra over more than a decade of transatlantic travel. Quite emotionally, he described Brazil as a kind of a 'garden of earthly delights' and talked of the passions and the affairs he had experienced there. Comparisons with life in Italy - work, leisure, intimacy punctuated his stories always to the detriment of his homeland. At the same time, he urged his workmate and another friend to emulate him (You have to go there with me - it's another world!) in an open attempt to convince them to accompany him on the next trip. At the end of the afternoon, Gentile's stories about Brazil continued in the car on the winding mountain road down to Aosta.

During the trip he told his friend about Brazilian women and their allegedly natural predisposition towards sexuality and seduction. To prove his point he gave the example of 'Carnatal' [the micareta, or out-of-season carnival in the city of Natal] and how, at that joyous event, women spontaneously kiss men on the mouth. His friend was quite impressed, clearly attributing a connotation to such behaviour that does not necessarily signify eroticism in its local context. Then he identified Brazil, especially Ponta Negra, as offering a much more pleasurable alternative to life in Aosta, mainly during its harsh winter climate: What do you do here in January or February?! With this cold you can't even leave the house! You can't get together with friends. There is nothing to do to pass the time. Everyone is shut up indoors. It's tough! It's much better to be on the beach at Ponta Negra! (field notes, Aosta, 10/10/2010)

The conversations about the time spent in the tropics are very common and seem to set a form of escape from the everyday routines and tensions in Italy. At work, these conversations of Gentile's are even more frequent, not least of all because one of his workmates is Ambrosini (43 years old, mason), precisely the person, who more than a decade ago, took him for the first time to the Northeast of Brazil. He is one of the many for whom the 
influence of a network of close social connections and the effects of word-of-mouth publicity (Camprubí, Guia, \& Comas, 2013; Gomes et al., 2010; Piscitelli, 2004b) provided the first major source of knowledge about Ponta Negra and the most important stimulus to his transatlantic tourism.

Although the Internet is neither the principal source of references nor the main factor in awakening potential visitors' interest in Ponta Negra, it is almost always used to collect additional information, and this makes it a key element in the process of decisionmaking about the trip and how the stay will be organized: I heard other people talking about it and then, using the Internet, I checked it out and I liked it. I talked to some friends who had already been in Ponta Negra and they told me that it was a bello posto' [nice place], completely different from Italy, from everything in Italy (Italian, 25 years old, factory worker). Nowadays, online resources provide many of the symbolic coordinates that structure the views of the prospective tourist and give a foretaste of what he may experience, thereby influencing the final choice of tourist destination. Urry (1996, p. 18) reminds us that 'places are chosen to be gazed upon because there is anticipation, especially through daydreaming and fantasy of intense pleasures, either on a different scale or involving different senses from those customarily encountered'. Mass-consumption Internet, TV, newspaper and magazine content feed anticipation of the tourist experience, allowing an image of a far-away place to be created without even leaving the house, ${ }^{12}$ and for sensory states to be attained corresponding to what Campbell (2005, pp. 77-95) termed 'imaginative hedonism'. The emotions and experiences evoked by content made available on global 'mediascapes' (Appadurai, 1996) - for example, in the audio-visual materials posted by satisfied visitors to Ponta Negra on YouTube ${ }^{13}$ - undoubtedly constitutes an important reference when potential tourists begin exercise their imaginations.

Notwithstanding the tourist-trade origin of some of the content referred to above, its role in the diffusion of information and in attracting overseas visitors is nonetheless probably less prominent than the role of informal social circuits and the Internet. The majority of tourists interviewed did not come to know about Ponta Negra through direct contact with official tourism bodies or through travel agencies, and did not even use them to organize their stays. As was mentioned before, knowledge about the destination was generated mainly in the closed circuits of male sociability, followed by the Internet, especially as a way of obtaining supplementary information. The most pervasive images and representations found in both these social spaces - namely those that favour the 'male gaze' and project Brazil as a 'male tourism landscape' (Pritchard \& Morgan, 2000) - provided the fundamental symbolic resources on which prospective visitors' imaginations worked, in turn formatting expectations that tend to boost transatlantic tourist mobility.

\section{Conclusion}

In general terms, the tourist experience provides the possibility of a transformation of the self (Bruner, 2004), albeit one that is mainly transitory and not so accentuated as to be life-changing. Tourism works mostly in accordance with the personal norms and values of the one experiencing it and '[ $[.$.$] is supposed to satisfy the need in a direction of$ further enhancement of these values, not to turn the tourist into an entirely different kind of person' (Graburn, 2004, p. 24). This situation is evident among European tourists in Ponta Negra (and potential tourists to the resort in Europe) whom I have interviewed during my fieldwork on both sides of the Atlantic, focusing particularly on the Italian tourists who constitute the vast majority visitors. The aims associated with their tourism experiences are mainly passional, and are inseparable from the dissatisfaction they feel towards 
the gender relationships and the forms of intimate life they encounter in Europe, as well as corresponding desire to experience configurations of intimacy that are closer to their own idealizations and expectations. The ostensibly excessive emancipation and detraditionalization of European women are repeatedly pointed to as the main cause for the emotional and relational turbulence European men experience. More specifically, they consider exaggerated feminine investment in careers and a disproportionate materialism that is detrimental to their emotional, sexual and family life, as the cause of what they claim, with a certain patriarchal nostalgia, to be the greatest problem in their intimate lives: the greater selectivity and intransigence of women - especially those they desire the most - in the process of seduction and in issues of sexuality; the difficulties in constructing unions according to the male ideals - consisting of a significant and intense affective-sexual complicity on the part of the female partner, complemented by her ongoing investment in maintaining a balance between family and career projects.

At a time when personal projects, relationships and practices extend more and more beyond national boundaries, Brazil represents a geography of (possible) change for these men. Unhappy with their love life in Europe, they are motivated by the possibility of finding in the other side of the Atlantic relationship patterns more similar to their own projects of marital and family life, and to their notions of what constitutes normality in conjugal relations, and what it means to be a man or a woman. The dominant representations of Brazil, intensely linked to sensuality and to the feminine, in particular to a sexualized notion of Brazilian women as warmer and more affectionate (and at the same time less emancipated) than their European counterparts, to a large extent help to feed the belief that the tropics will be an effective alternative to the Western 'chaos of love' (Beck \& Beck-Gernsheim, 2004) and a context more conducive to the practices on which 'hegemonic masculinity' (Connell, 1995) is based. For those who do not know the tourist destination, the tales of others who have already been there decisively help to reinforce the appealing images of Brazil and to shape the expectations that will induce a specific visit to be undertaken. Moreover, these tales are also constituent elements of the male sociability processes in which the majority of the tourist flows from Europe to Ponta Negra take place. The environment created by homosociability, the volatility of intimacy in European context, and the symbolic weight of 'brazilianness', constitute three crucial sociocultural frameworks that help to explain the genesis, materialization and evolution of this particular form of transatlantic tourism.

\section{Disclosure statement}

No potential conflict of interest was reported by the author.

\section{Funding}

This field research was supported by a Ph.D. grant of the Portuguese Foundation for Science and Technology [FCT - SFRH/BD/60862/2009] and the writing process of this article by the Centre for Transdisciplinary Development Studies of the University of Trás-os-Montes and Alto Douro [centre financed by FCT - PEst-OE/SADG/UI4011/2014].

\section{Notes}

1. The fieldwork was based on a qualitative methodological approach, with ethnography being the guiding procedure for data collection (through participant observation and semi-oriented interviews), although I have also undertaken documental research and applied a short questionnaire 
to characterize European tourists to the area. First, I stayed six months in Ponta Negra, between November 2009 and May 2010, this constituting the initial ethnographic context and principal point of reference. In addition, I visited other sites - geographical (the North of Italy and the Netherlands) and digital (e.g. Facebook and YouTube) - involved in the dense network of flows associated with the connections of intimacy that had begun in Brazil, some of which had been maintained over time at distance in several relational formats. Thus, by adopting a 'multi-sited ethnography' (Marcus, 1995), I was able to keep contact with some of my main informants during their trips to and stays in locations on both sides of the Atlantic and, therefore, gain a more complete understanding of the transnational dimension of what might be called 'intimacy-scapes' in which they are the main characters. The fact of being a male researcher facilitated a particularly empathetic relationship with the European men. Furthermore, my Portuguese nationality and the sharing of a common language helped in the process of developing closer contact with the Brazilian women involved. Additionally, these factors also played a positive role in establishing a rapport with the majority of tourists, due to our proximity in terms of geography, culture and language.

2. It is pertinent to recall here Enloe's claim (cited in Carter \& Clift, 2000, p. 9) that historically the tourist trip is a profoundly gendered (i.e. male) experience.

3. Compared to the South of Italy, the percentage of bachelors in the North is higher, on average they marry later, the nuptiality quotient is weaker $(2.8 \%$ in the Northwest and $2.9 \%$ in the Northeast, both lower than the national average of $3.2 \%$, and even lower than the $3.8 \%$ o found in the South of the country) (Istituto Nazionale di Statistica - Itália [ISTAT], 2013) and the rate of divorce is higher (ISTAT, 2012).

4. One can infer from the educational and employment data that these visitors to Ponta Negra are not from the wealthiest classes, which goes in line with the more or less explicit statements of Piscitelli (2004b) on Fortaleza (Brazil), Brennan (2004a) on Sosúa (Dominican Republic), Taylor (2000) on the Caribbean region, or Cohen (1982, 2003) and Seabrook (1996) on locations in Thailand. This fact is a symptom of a rising democratization of travelling and the wider societal diffusion of what was hitherto an elite culture of tourism consumption (Hall, 2015; Urry, 1996).

5. Generally, language differences did not constitute a problem when interviewing tourists. For many, as a result of their repeat visits to Brazil, they were already quite comfortable with the Portuguese language. In the case of Italian, the relative proximity between the two languages proved to be a facilitating factor for communication and for the subsequent transcription of interviews.

6. This shift, according to Kaufmann (2000), is towards a more self-affirming focus on themselves, on the creation of a 'solo lifestyle' detached from traditional family canons, and involves a perpetual search for a 'fairytale prince'.

7. Moreover, the references to Briatore and to Totti show that ' $[\ldots]$ hegemony works in part through the production of exemplars of masculinity (e.g., professional sports stars), symbols that have authority despite the fact that most men and boys do not fully live up to them' (Connell \& Messerschmidt 2005: 846). In Italy, 'hegemonic masculinity' is rooted, in particular, in multiple cultural expressions from antiquity to the present, relating to collective representations of the country's identity, and in the politico-ideological construction of nationality and of what it means to be Italian (Bellassai, 2008; Cecla, 2010; Reich, 2004).

8. A woman who meets the criteria of beauty and sensuality most appreciated and desired by the public. Though the origins of the metaphorical use of the word velina (literally 'tissue paper') were in the fascist period - when journalists used it to refer to news content disseminated by the regime aiming strategically to produce a certain version of the facts - by the end of the 1980s, it had come to mean a TV showgirl, modelled on the young women in Channel 5's popular satire show Striscia la Notizia, broadcast since 1988.

9. According to these men's viewpoints, Brazilian women prefer more patriarchal settings, embodying what Connell and Messerschmidt (2005) termed an 'emphasized femininity'. However, it was not only women who have supposedly changed. They and the coordinates of gender relationships also changed. Tourist travel, as is the case with many other forms of mobility, modifies the ways in which these men perceive, present and fulfil their gender identity (Cresswell \& Uteng, 2008).

10. In Italy, in the rest of Europe and in developed countries as a whole, formal marriage has been losing some of its hegemony as a conjugal model, with romantic unions becoming progressively 
deinstitutionalized and more flexible (Aboim, 2004; Hull, Meier, \& Ortyl, 2010; Rosina \& Fraboni, 2004).

11. The retelling is almost always done in an affectionate way, either more enthusiastically or in a more nostalgic manner. The story is, in some cases, embellished by showing photos and short videos, often made available publicly through YouTube and/or other online social networks. Souvenirs can also be an important trigger for the recounting of tourist experiences, as Stewart (cited in Löfgren, 2004, p. 100) has highlighted. I witnessed conversations that started simply due to the sound of forró music from the Brazilian North-East, or to the sight of a key-fob or of yellow-and-green scarves on a car's front seats, loudly proclaiming their Brazilian origins.

12. 'Armchair tourism' (Baxter \& Pieszek, 2011) is a common term for such practices.

13. Easily accessed internationally and viewed by tens of thousands of people, particularly in European countries where the greatest touristic flows originate.

\section{ORCID}

Octávio Sacramento (D) http://orcid.org/0000-0001-8533-3653

\section{References}

Aboim, S. (2004). Conjugalidades em mudança. Percursos, orientações e dinâmicas da vida a dois. Lisboa: ICS.

Alfonso, L. (2006). Embratur: Formadora de imagens da nação brasileira (Unpublished master's thesis). State University of Campinas, Campinas, Brazil.

Almeida, M. V. (1995). Senhores de si: Uma interpretação antropológica da masculinidade. Lisboa: Fim-de-Século.

Appadurai, A. (1996). Modernity at large: Cultural dimensions of globalization. Minneapolis: University of Minnesota Press.

Bandyopadhya, R. (2013). A paradigm shift in sex tourism research. Tourism Management Perspectives, 6, 1-2. doi:10.1016/j.tmp.2012.09.001

Bauman, Z. (2008). Amor líquido: Sobre a fragilidade dos laços humanos. Lisboa: Relógio d'Água.

Baxter, A., \& Pieszek, L. (2011). Armchair tourism: Bringing the world into your living room. In A. Papathanassis (Ed.), The long tail of tourism: Holiday niches and their impact on mainstream tourism (pp. 171-183). Wiesbaden: Gabler Verlag.

Beck, U., \& Beck-Gernsheim, E. (2004). The normal chaos of love. Cambridge, MA: Polity Press.

Bellassai, S. (2008). La mascolinità contemporanea. Rome: Carocci.

Bignami, R. (2002). A imagem do Brasil no turismo. São Paulo: Aleph.

Billari, F., \& Rosina, A. (2007). Famiglia e vita di coppia oggi in Italia. In E. Jussi (Ed.), Personal manager: L'economia della vita quotidiana. La famiglia (Vol. 4, pp. 151-183). Milan: Egea Università Bocconi.

Bishop, R., \& Robinson, L. (1998). Night market: Sexual cultures and the Thai economic miracle. London, NY: Routledge.

Blanchette, T., \& Silva, A. P. (2010). 'A mistura clássica': Miscigenação e o apelo do Rio de Janeiro como destino para o turismo sexual. Bagoas, 4(5), 221-244.

Bozon, M. (2004). Sociologia da sexualidade. Rio de Janeiro: FGV.

Brennan, D. (2004a). What's love got to do with it? Transnational desires and sex tourism in the Dominican Republic. Durham: Duke University Press.

Brennan, D. (2004b). When sex tourists and sex workers meet: Encounters within Sosúa, the Dominican Republic. In S. Gmelch (Ed.), Tourists and tourism: A reader (pp. 303-315). Long Grove, IL: Waveland Press.

Bruner, E. (2004). Tourism in the Balinese borderzone. In S. Gmelch (Ed.), Tourists and tourism: A reader (pp. 219-238). Long Grove, IL: Waveland Press.

Campbell, C. (2005). The romantic ethic and the spirit of modern consumerism. London: Alcuin Academics.

Camprubí, R., Guia, J., \& Comas, J. (2013). The new role of tourists in destination image formation. Current Issues in Tourism, 16(2), 203-209. doi:10.1080/13683500.2012.733358 
Carrier-Moisan, M.-E. (2012). Gringo love: Affect, power, and mobility in sex tourism, Northeast Brazil (Doctoral dissertation, University of British Columbia, Canada). Retrieved February 12, 2015, from http://circle.ubc.ca/bitstream/handle/2429/41922/ubc_2012_spring_carriermoisan_ marieeve.pdf?sequence $=3$

Carter, S., \& Clift, S. (2000). Tourism, international travel and sex: Themes and research. In S. Clift, \& S. Carter (Eds.), Tourism and sex: Culture, commerce and coercion (pp. 1-19). London: Pinter. Cecla, F. (2010). Modi bruschi: Antropologia del maschio. Milan: Elèuthera.

Cohen, E. (1982). Thai girls and Farang men: The edge of ambiguity. Annals of Tourism Research, 9, $403-428$.

Cohen, E. (2003). Transnational marriage in Thailand: The dynamics of extreme heterogamy. In T. Bauer, \& B. McKercher (Eds.), Sex and tourism: Journeys of romance, love and lust (pp. 57-81). New York, NY: Haworth Press.

Connell, R. (1995). Masculinities. Cambridge, MA: Polity Press.

Connell, R., \& Messerschmidt, J. (2005). Hegemonic masculinity: Rethinking the concept. Gender \& Society, 19(6), 829-859.

Constable, N. (2003). Pen pals, virtual ethnography, and 'mail order' marriages: Romance on a global stage. Berkeley, CA: University of California Press.

Coontz, S. (2004). The world historical transformation of marriage. Journal of Marriage and Family, 66(4), 974-979. doi:10.1111/j.0022-2445.2004.00067.x

Cresswell, T., \& Uteng, T. (2008). Gendered mobilities: Towards an holistic understanding. In T. Uteng \& T. Cresswell (Eds.), Gendered mobilities (pp. 1-12). Aldershot: Ashgate.

Fernandez, N. (1999). Back to the future? Women, race, and tourism in Cuba. In K. Kempadoo (Ed.), Sun, sex, and gold: Tourism and sex work in the Caribbean (pp. 81-89). Lanham, MD: Rowman $\&$ Littlefield.

Filho, A. S. (2011). Brésil: Terre de métissages - Imaginaire et quotidien dans la société brésilienne. Sarrebruck: Éditions Universitaires Européennes.

Garrick, D. (2005). Excuses, excuses: Rationalisations of Western sex tourists in Thailand. Current Issues in Tourism, 8(6), 497-509. doi:10.1080/13683500508668233

Giddens, A. (2001). Transformações da intimidade: Sexualidade, amor e erotismo nas sociedades modernas. Oeiras: Celta.

Gomes, D., Silva, Á., Cavalcante, A., \& Fonteles, A. (2010). Acuarela multicolor: Brasil pintado por los turistas extranjeros. Estudios y Perspectivas en Turismo, 19(5), 607-655.

Graburn, N. (2004). Secular ritual: A general theory of tourism. In S. Gmelch (Ed.), Tourists and tourism: A reader (pp. 23-34). Long Grove, IL: Waveland Press.

Hall, C. (2015). On the mobility of tourism mobilities. Current Issues in Tourism, 18(1), 7-10. doi:10. $1080 / 13683500.2014 .971719$

Hall, S. (2007). A identidade cultural na pós-modernidade. Rio de Janeiro: DP\&A.

Hoefinger, H. (2013), Sex, love and money in Cambodia: Professional girlfriends and transactional relationships. Abingdon: Routledge.

Hull, K., Meier, A., \& Ortyl, T. (2010). The changing landscape of love and marriage. Contexts, 9(2), 32-37. doi:10.1525/ctx.2010.9.2.32

Illouz, E. (1999). The lost innocence of love: Romance as a postmodern condition. In M. Featherstone (Ed.), Love \& eroticism (pp. 161-186). London: Sage.

Istituto Nazionale di Statistica. (2012). La rilevazione sulle separazioni e sui divorzi. Retrieved January 28, 2015, from http://demo.istat.it/altridati/separazionidivorzi/index.html

Istituto Nazionale di Statistica. (2013). La rilevazione sui matrimoni. Retrieved January 28, 2015, from http://demo.istat.it/altridati/matrimoni/

Kaufmann, J.-C. (2000). A mulher só e o príncipe encantado: Inquérito sobre a vida a solo. Lisboa: Editorial Notícias.

Kempadoo, K. (Ed.). (1999). Sun, sex, and gold: Tourism and sex work in the Caribbean. Lanham, MD: Rowman \& Littlefield.

Knauth, D., Víctora, C., Leal, A., \& Fachel, J. (2006). As trajetórias afetivo-sexuais: Encontros, uniões e separação. In M. Heilborn, E. Aquino, M. Bozon, \& D. Knauth (Eds.), O aprendizado da sexualidade: Um estudo sobre reprodução e trajetórias sociais de jovens brasileiros (pp. 267307). Rio de Janeiro: Fiocruz/Garamond.

Leheny, D. (1995). A political economy of Asian sex tourism. Annals of Tourism Research, 22(2), $367-384$. 
Leung, P. (2003). Sex tourism: The case of Cambodia. In T. Bauer, \& B. McKercher (Eds.), Sex and tourism: Journeys of romance, love and lust (pp. 181-195). New York, NY: Haworth Press.

Löfgren, O. (2004). Narrating the tourist experience. In S. Gmelch (Ed.), Tourists and tourism: A reader (pp. 91-108). Long Grove, IL: Waveland Press.

Machado, I. (2009). Cárcere público: Processos de exotização entre brasileiros no Porto. Lisboa: ICS.

Manderson, L., \& Jolly, M. (Eds.). (1997). Sites of desireleconomies of pleasure: Sexualities in Asia and the Pacific. Chicago, IL: University of Chicago Press.

Marcus, G. (1995). Ethnography in/of the world system: The emergence of multi-sited ethnography. Annual Revue of Anthropology, 24, 95-117.

McClintock, A. (1995). Imperial leather: Race, gender and sexuality in the colonial context. London: Routledge.

O'Connell-Davidson, J. (1996). Sex tourism in Cuba. Race and Class, 38(1), 39-48. doi:1177/ 030639689603800103

O'Connell-Davidson, J. (2001). The sex tourist, the expatriate, his ex-wife and her 'other': The politics of loss, difference and desire. Sexualities, 41(1), 5-24. doi:10.1177/136346001004001001

Oppermann, M. (1999). Sex tourism. Annals of Tourism Research, 26(2), 251-266.

Oppermann, M., \& McKinley, S. (1997). Sexual imagery in the marketing of Pacific tourism destinations. In M. Oppermann (Ed.), Pacific rim tourism (pp. 116-127). Wallingford: CAB International.

Piscitelli, A. (2004a). El tráfico del deseo: Interseccionalidades no marco do turismo sexual no Nordeste do Brasil. Quaderns-e, 4, 1-15. Retrieved December 14, 2011, from http://www. antropologia.cat//antiga/quaderns-e/04/04_03.htm\#4

Piscitelli, A. (2004b). On 'gringos' and 'natives': Gender and sexuality in the context of international sex tourism. Vibrant - Virtual Brazilian Anthropology, 1(1-2), 87-114. Retrieved January 21, 2011, from http://www.vibrant.org.br/issues/v1n1/adriana-piscitelli-on-gringos-and-natives/

Piscitelli, A. (2007). Shifting boundaries: Sex and money in the North-East of Brazil. Sexualities, 10(4), 489-500. doi:10.1177/1363460707080986

Piscitelli, A. (2009). Tránsitos: Circulación de brasileñas en el ámbito de la transnacionalización de los mercados sexual y matrimonial. Horizontes Antropológicos, 15(31), 101-136. doi:10.1590/ S0104-71832009000100005

Pritchard, A., \& Morgan, N. (2000). Privileging the male gaze: Gendered tourism landscape. Annals of Tourism Research, 27(4), 884-905. doi:10.1016/S0160-7383(99)00113-9

Rao, N. (1999). Sex tourism in South Asia. International Journal of Hospitality Management, 11(2), 86-99. doi:10.1108/09596119910250940

Reich, J. (2004). Beyond the Latin lover: Marcello Mastroianni, masculinity, and Italian cinema. Bloomington: Indiana University Press.

Ribeiro, F. B., \& Sacramento, O. (2009). Imagens, erotismo e culturas on the road: Perspectivas sobre o Brasil como destino turístico. Configurações, 5-6, 241-255. doi:10.4000/configuracoes.472

Roca, J. (2007). Migrantes por amor. La búsqueda y formación de parejas transnacionales. AIBR Revista de Antropología Iberoamericana, 2(3), 430-458.

Roca, J. (2008). Ni contigo ni sin ti: cambios y transformaciones en los roles de género y las formas de convivencia. In A. Téllez \& J. Martínez (Eds.), Sexualidad, género, cambio de roles y nuevos modelos de familia (pp. 13-31). Elche: SIEG/Universidad Miguel Hernández.

Rosina, A., \& Fraboni, R. (2004). Is marriage losing its centrality in Italy? Demographic Research, 11, 149-172. doi:10.4054/DemRes.2004.11.6

Ryan, C. (2000). Sex tourism: Paradigms of confusion? In S. Clift \& S. Carter (Eds.), Tourism and sex: Culture, commerce and coercion (pp. 23-40). London: Pinter.

Sacramento, O. (2011). Homens em férias abaixo do equador: Questionando a sustentabilidade empírica do conceito de turismo sexual. In Proceedings of the international conference on tourism \& management studies (pp. 1189-1192). Faro: University of Algarve.

Sacramento, O. (2014). Atlântico passional: Mobilidades e configurações transnacionais de intimidade euro-brasileiras (Unpublished doctoral dissertation). ISCTE-IUL, Lisbon, Portugal.

Sacramento, O., \& Ribeiro, F. B. (2013). Trópicos sensuais: A construção do Brasil como geografia desejada. Bagoas, 7(10), 215-232.

Seabrook, J. (1996). Travels in the skin trade: Tourism and the sex industry. London, IL: Pluto Press.

Simoni, V. (2014). Coping with ambiguous relationships: Sex, tourism, and transformation in Cuba. Journal of Tourism and Cultural Change, 12(2), 166-183. doi:10.1080/14766825.2014.915093 
Sommer, D. (2004). Ficções de fundação: Os romances nacionais da América Latina. Belo Horizonte: UFMG.

Stolcke, V. (2006). O enigma das intersecções: Classe, 'raça', sexo, sexualidade. A formação dos impérios transatlânticos do século XVI ao XIX. Estudos Feministas, 14(1), 15-42. doi: 10. 1590/S0104-026X2006000100003

Taylor, J. (2000). Tourism and 'embodied' commodities: Sex tourism in the Caribbean. In S. Clift, \& S. Carter (Eds.), Tourism and sex: Culture, commerce and coercion (pp. 41-53). London, NY: Pinter.

Taylor, J. (2001). Dollars are a girl's best friend? Female tourists' sexual behaviour in the Caribbean. Sociology, 35, 749-764. doi: 10.1177/S0038038501000384

Trumbull, C. (2001). Prostitution and sex tourism in Cuba. Cuba in Transition, 11, 356-371.

Truong, T.-D. (1983). The dynamics of sex tourism: The case of Southeast Asia. Development and Change, 14(4), 533-553.

Truong, T.-D. (1990). Sex, money and morality: Prostitution and tourism in Southeast Asia. London: Zed Books.

Urry, J. (1996). O olhar do turista: Lazer e viagens nas sociedades contemporâneas. São Paulo: Studio Nobel.

Veissière, S. (2011). Ghosts of empire: Sex, mobility, and violence in the transatlantic cultural economy of desire. Berlin: LIT Verlag.

Williams, E. (2013). Sex tourism in Bahia: Ambiguous entanglements. Urbana: University of Illinois Press. 